\title{
Influence of low temperatures on the survival of the Pacific oyster (Crassostrea gigas) infected with Ostreid herpesvirus type 1
}

\author{
Pernet Fabrice ${ }^{1, *}$, Tamayo David ${ }^{2}$, Petton Bruno ${ }^{3}$
}

${ }^{1}$ Ifremer, UMR LEMAR 6539 (UBO/CNRS/IRD/Ifremer), Technopole de Brest-Iroise, BP 7029280

Plouzané, France

${ }^{2}$ Departamento GAFFA (Animal Physiology), Facultad de Ciencia y Tecnología, Universidad del País

Vasco/Euskal Herriko Unibertsitatea, Apartado 644, 48080 Bilbao, Spain

${ }^{3}$ Ifremer, UMR LEMAR 6539 (UBO/CNRS/IRD/Ifremer), 11 presqu'île du Vivier, 29840 Argenton-en-

Landunvez, France

* Corresponding author : Fabrice Pernet, email address : fabrice.pernet@ifremer.fr

\begin{abstract}
:
Mortalities of oyster seed of Crassostrea gigas associated with ostreid herpes virus OsHV-1 $\mu$ Var have been observed in many oyster producing countries since 2008. The objective of this study was to further investigate whether low temperature treatments can offer a viable option to mitigate oyster mortalities. An experiment was set-up to further evaluate the effect of low temperature treatments $\left(10\right.$ and $13^{\circ} \mathrm{C}$ vs. $\left.21^{\circ} \mathrm{C}\right)$ and their duration ( $6 \mathrm{~d}$ to $83 \mathrm{~d}$ ) on the survival of oysters previously infected with OsHV-1 $\mu \mathrm{Var}$ by means of exposure to field conditions in areas where mortalities were occurring. Average survival of oysters infected with OsHV-1 $1 \mu$ Var was $71 \%$ after $83 \mathrm{~d}$ at low temperatures compared to only $23 \%$ in controls maintained at $21^{\circ} \mathrm{C}$. During cold-exposure, levels of OsHV-1 DNA in oyster tissues gradually decreased, down to nearly the detection limit after $24 \mathrm{~d}$. However, when cold-acclimated oysters were suddenly exposed at $21^{\circ} \mathrm{C}$ in the laboratory, they exhibited high levels of mortality along with an enhancement of OsHV-1 DNA concentration in their tissues. Therefore, OsHV-1 persists in oysters even at low temperature and is reactivated during subsequent thermal elevation to $21^{\circ} \mathrm{C}$. Low temperature treatments did not improve overall survival of oyster seed infected with OsHV-1. These results suggest that moving infected oysters to a cooler area only delays mortality and may increase the risk of infection in neighbouring stocks when rising temperatures become permissive for viral replication.
\end{abstract}

\section{Highlights}

- The herpesvirus OsHV-1 is persistent in oysters at low temperature and it is reactivated during thermal elevation to $21^{\circ} \mathrm{C}$. The reactivation of the virus can occur several weeks to months after the initial exposure and appears to be temperature dependent. - From a practical standpoint, overall survival of oyster seed infected with OsHV-1 was not improved by low temperature treatments.

Keywords : Bivalve, Disease, OsHV-1, Oyster, Temperature, Virus 


\section{Introduction}

Since 2008, mass mortalities of oyster seed of Crassostrea gigas have been reported in several European countries in relation to the detection of a particular genotype of the Ostreid Herpes Virus 1 (OsHV-1) called $\mu$ Var (EFSA 2010, Segarra et al. 2010, Martenot et al. 2011, Lynch et al. 2012, Peeler et al. 2012, Roque et al. 2012). These mortalities affected all rearing sites along French coasts when seawater temperature exceeds $16^{\circ} \mathrm{C}$ (Pernet et al. 2012, Petton et al. 2013, Renault et al. 2014). However, oysters infected with OsHV-1 $\mu$ Var and further maintained at $13{ }^{\circ} \mathrm{C}$ for 40 days in the laboratory show no mortality, are negative for OsHV-1 and do not transmit the disease to healthy oysters (Petton et al. 2013). Therefore, the maintenance of infected oysters at low temperatures may offer a way to mitigate OsHV-1 related mortalities. But, the long-term survival of these cold-acclimated, previously infected and cold-acclimated oysters needs to be further evaluated, notably in field conditions where mortalities are occurring. In addition, the protocol for cold-exposure requires fine-tuning i.e. testing of several combinations of low temperatures and duration of application, and validation at a larger scale.

The objective of the present study was to evaluate the effect of low temperatures on the long term survival of oysters previously infected with OsHV-1 $\mu$ Var. To this purpose, naïve oyster seed were exposed for 5 and 8 days to field conditions where mortalities were occurring and were maintained at low temperatures $\left(10^{\circ} \mathrm{C}\right.$ and $\left.13^{\circ} \mathrm{C}\right)$ in the laboratory for time varying between $6 \mathrm{~d}$ and $83 \mathrm{~d}$. Then, oysters were either exposed to a thermal challenge in the laboratory $\left(21^{\circ} \mathrm{C}\right)$ to check for activation of the virus, or transferred back to field site where mortalities were actively occurring to evaluate the survival of cold-acclimated oyster seed.

\section{Material and methods}

\subsection{Animals}

Experimental oysters were produced as previously described in Petton et al. (2015). Briefly, broodstock originating from wild oyster population located in Fouras (Marennes-Oléron, France, 46 ${ }^{\circ} 00^{\prime} 43.2^{\prime \prime} \mathrm{N}, 1^{\circ} 07^{\prime} 02.9^{\prime \prime} \mathrm{W}$ ) were collected in August 2009 and 2010, and placed in mesh-bags in February 2010 and 2011 for transfer to a grow-out farm located in Aber Benoît, (northern Brittany, France, 48³4'29.976’' N, 4³6’18.378', W).

On January $8^{\text {th }} 2013$, 40 adult oysters were moved to the Ifremer facilities in Argenton (Brittany, France, 48 31 '16.320’' N, 446’01.998', W) for conditioning during 5 weeks. 
These animals were held in 500-L flow-through tanks with seawater at $16^{\circ} \mathrm{C}$ enriched with a phytoplankton mixture. Seawater was treated with UV and filtered at $1 \mu \mathrm{m}$. The daily mixed diet consisted of Isochrysis affinis galbana (CCAP 927/14) and Chaetoceros gracilis (UTEX LB2658) $1: 1$ in dry weight at a ration equivalent to $6 \%$ of the oyster dry weight. Once the oysters were reproductively mature, gametes from 40 individuals ( $1 / 3$ males, 2/3 females), obtained by stripping, were mixed in a 5-L jar at a ratio of 50 spermatozoids per oocyte. Fertilization and larval rearing were conducted as previously described in Petton et al. (2015). When oysters were $>2 \mathrm{~mm}$ shell length on April $11^{\text {th }} 2013$, they were transferred to the Ifremer nursery in Bouin (Vendée, France, 46 $57^{\prime} 15.5^{\prime \prime} \mathrm{N} 2^{\circ} 02^{\prime} 40.9^{\prime \prime} \mathrm{W}$ ). Experimental oysters were transferred back to Argenton mid-June 2013. Oyster seed did not exhibit mortality at $21^{\circ} \mathrm{C}$ under laboratory conditions and OsHV-1 DNA was not detected. Therefore, oyster seed was considered as naïve with regard to OsHV-1 $\mu$ Var.

\subsection{Experimental design}

A schematic of the experiment is shown in Fig. 1. Average whole body wet weight of oysters was $0.94 \mathrm{~g}$ and age was 5.5 months at the start of the experiments.

\subsubsection{Field exposure}

On July $5^{\text {th }}$, subsample of oyster seed (ca. 22000 individuals) was transferred to a farming area located in the Bay of Brest at Pointe du Chateau (48 20'06.19” N, $4^{\circ} 19^{\prime} 06.37^{\prime}$ ' W, seawater temperature $=18.0^{\circ} \mathrm{C}$, Fig. 2) where mortalities were occurring among local oysters, while the remaining oysters were held at the Ifremer facilities in $500-\mathrm{L}$ tanks at $21^{\circ} \mathrm{C}$. Oysters in the bay of Brest were kept in mesh bags ( $c a$. 300 individuals per bag) attached to iron tables. Field exposure lasted for $5 \mathrm{~d}$ or $8 \mathrm{~d}$, and oyster seed was transferred back to the Ifremer facilities in Argenton on July $9^{\text {th }}$ or $12^{\text {th }}$ respectively. The oysters exposed to field conditions (presumably infected with OsHV-1) and those maintained in the laboratory (presumably naïve) were either exposed to low temperatures $\left(10^{\circ} \mathrm{C}\right.$ or $\left.13^{\circ} \mathrm{C}\right)$ or to $21^{\circ} \mathrm{C}$ (control). The field-exposed oysters used in the experiments did not show any mortality during the exposure periods in the field prior to returning back to the laboratory. Subsamples of the exposed oyster batches were left in the field to examine whether they suffered mortalities subsequently.

\subsubsection{Low temperature treatments}

Oysters exposed to low temperature were placed in 8 rectangular 500-L flow-through tanks with seawater at $10^{\circ} \mathrm{C}$ or at $13^{\circ} \mathrm{C}(2$ treatments [exposed vs. naïve] $\times 2$ duration of field exposure $[5 \mathrm{~d}$ vs. $8 \mathrm{~d}] \times 2$ temperature $\left[10^{\circ} \mathrm{C}\right.$ vs. $\left.\left.13^{\circ} \mathrm{C}\right]\right)$. Each treatment combination was 
applied to a unique tank with no replication (Fig. 1). Each tank contained ca. 5400 oysters. All the tanks were placed in the same room with controlled air temperature $\left(10^{\circ} \mathrm{C}\right)$. Seawater temperatures were maintained constant throughout the study period using thermo-regulated automatic valves. Oysters were fed the same diet as the broodstock at a concentration of 1500 $\mu \mathrm{m}^{3}$ per $\mu \mathrm{L}$. Food concentrations, seawater temperature and oxygen saturation were measured twice daily on each of the experimental tanks, and flow rates were adjusted accordingly. Dead oysters were counted at the start of the experiment (day 0 or 3 for oysters exposed to field conditions for $5 \mathrm{~d}$ or $8 \mathrm{~d}$ respectively), and after $6,8,10,13,15,21$ or 24,41 or 44,62 or 64 , and $83 \mathrm{~d}$ (Fig. 1). Two pools of five oysters were sampled in each tank for OsHV-1 DNA detection on days 6,21 or 24,41 or 44 and 62 or $64 \mathrm{~d}$ since the start of the experiment. At these times, subsamples of 560 individuals were removed from each tank for challenge experiments.

\subsubsection{Challenge experiments}

Challenge experiments consisted in (1) exposing subsamples of oysters (280 individuals) from each condition to a thermal elevation to $21^{\circ} \mathrm{C}$ in the laboratory to activate OsHV-1 in asymptomatic carriers (Petton et al. 2015), or (2) transferring the remaining subsamples to the farming area in the Bay of Brest where mortalities were occurring (Fig. 1).

\subsubsection{Thermal challenge}

The thermal challenge was conducted on oysters at their arrival in the laboratory ( $\mathrm{d} 0$ ), and after 6,21 or 24,41 or 44 and 62 or $64 \mathrm{~d}$ since the start of the low temperature treatment. The oysters were placed in duplicate $23-\mathrm{L}$ plastic tanks at $21^{\circ} \mathrm{C}(\mathrm{n}=2$ tanks for each condition at 140 individuals per tank) for $15 \mathrm{~d}$ to $21 \mathrm{~d}$. Additionally, two subsamples of oyster seed maintained at $21^{\circ} \mathrm{C}$ in $500-\mathrm{L}$ tanks (not previously exposed to field conditions nor low temperature) were also placed in duplicate 23 -L tanks at $21^{\circ} \mathrm{C}$ as control. Each tank was supplied with filtered $(1 \mu \mathrm{m}) \mathrm{UV}$ irradiated seawater flowing at $100 \mathrm{ml} \mathrm{min}{ }^{-1}$. Animals were fed the same diet as the broodstock at a concentration of $1500 \mu \mathrm{m}^{3}$ per $\mu \mathrm{L}$. Dead oysters were counted at the end of each challenge. Additionally, pools of 5 oysters were collected in each of the 23-L tanks 3-4 days after the onset and at the end of the thermal challenge for OsHV-1 DNA detection.

\subsubsection{Field transfer}

In parallel to the thermal challenge, the remaining subsamples of oysters were transferred to the farming area in the Bay of Brest where mortalities were occurring while seawater 
temperature was $>16^{\circ} \mathrm{C}$ (Fig. 2). Oysters were placed in duplicate mesh bags at a density of 140 individuals per bag. As for the thermal challenge experiment, subsamples of oyster seed maintained at $21^{\circ} \mathrm{C}$ in $500-\mathrm{L}$ tanks (not previously exposed to field conditions nor low temperatures) were also deployed in duplicate mesh bags as control. Due to logistical limitation, dead oysters were counted only once on 5 November 2013, after the diseasemortality period, while seawater temperature was $<14^{\circ} \mathrm{C}$ (Fig. 2), and the mortality event had passed. OsHV-1 DNA PCR assay was not conducted because it lacks sensitivity for detecting latent infection or asymptomatic carrier of the disease on pooled samples (Petton et al. 2015).

\subsection{Quantification of $O s H V-1 D N A$}

Oysters sampled for OsHV-1 DNA detection were stored at $-20^{\circ} \mathrm{C}$ until analysis. DNA extraction and OsHV-1 detection by PCR were performed by LABOCEA (Quimper, France).

Total DNA was extracted from an aliquot of tissue sample using a QIAgen QIAamp tissue mini kit, according to the manufacturer's protocol. The extracted DNA was stored at $-20^{\circ} \mathrm{C}$ prior to pathogen detection and quantification. The detection and quantification of OsHV-1 DNA was carried out using a previously published real-time PCR protocol (Pepin et al. 2008). Briefly, this protocol uses SYBR $®$ Green chemistry with specific DPFor/Rev primers targeting the region of the OsHV-1 genome predicted to encode a DNA polymerase catalytic subunit (Webb et al. 2007). The method used in our study is the recommended method for reasons of availability, utility, and diagnostic specificity and sensitivity for OsHV-1 detection (OIE 2012). Results were expressed as viral DNA copy numbers $\mathrm{mg}^{-1}$ wet tissue.

The standard real-time PCR using SYBR green cannot differentiate OsHV-1 reference from OsHV-1 $\mu$ Var. Therefore, specific primers were used to distinguish the "reference" and the " $\mu$ Var" genotypes by comparison with positive controls (EFSA 2011, Council regulation 175/2010, see appendix B). These complementary OsHV-1 $\mu$ Var specific PCR analyses were performed every 10 samples in which OsHV-1 DNA had first been detected. OsHV-1 $\mu$ Varspecific PCR analyses detected OsHV-1 $\mu$ Var genotype only, which agrees well with the fact that in 2009 the OsHV-1 $\mu$ Var had fully replaced the reference OsHV-1 genotype in seed presenting mortality in all French oyster production sites (Segarra et al. 2010, Martenot et al. 2011, Renault et al. 2012). Therefore, in the present study, we refer to "OsHV-1" as "OsHV-1 $\mu$ Var".

In our study, the likely minimum level of disease prevalence was less than $30 \%$ (with $95 \%$ confidence level), considering that 10 oysters ( 2 pools of 5 individuals for each tank or each 
treatment combination) were analysed for OsHV-1 DNA detection by qPCR, that there was no loss of sensitivity due to pooling and that the population of oysters is infinite (Pfeiffer 2010).

\subsection{Monitoring of seawater temperature in the field}

Seawater temperatures were provided by the Resco/Velyger Ifremer networks (http://wwz.ifremer.fr/velyger). Temperatures have been recorded every 30 min since March 2009 using multi-parameters probes (NKE Instrumentation) deployed at our experimental sites in the Bay of Brest at Pointe du Château (48 $20^{\prime} 06.19^{\prime \prime}$ N, $4^{\circ} 19^{\prime} 06.37^{\prime \prime}$ W, Fig. 2).

\subsection{Survival analyses}

The statistical analyses were conducted using LIFETEST, LOGISTIC and PHREG procedures of the SAS software package (SAS 9.4, SAS institute, Carry, USA). A significant threshold of 0.05 was adopted for all statistical tests. Survival of naïve oysters (not exposed to field condition) were not presented nor included in statistical models because it was always $100 \%$.

\subsubsection{Life tables}

Nonparametric estimates of the survivor function were computed by the Kaplan-Meier method (Kaplan \& Meier 1958). Survival time was measured as days from onset of experiment (d0, Fig. 1), when oysters were transferred back to the Ifremer facilities in Argenton. The data were read as the number of dead animals within each experimental unit at each time interval. Survival curves of exposed oysters were plotted and compared among treatment combinations ( 2 duration of field exposure $[5 \mathrm{~d}$ vs. $8 \mathrm{~d}] \times 3$ temperature $\left[10^{\circ} \mathrm{C}\right.$, $13^{\circ} \mathrm{C}$ and $21^{\circ} \mathrm{C}$, see Fig. 3).

\subsubsection{Cox regression}

The survival time curves of oysters were compared using the Cox regression model (Cox 1972), after adjustment for the effect of some static covariates such as duration of field exposure $(5 \mathrm{~d}$ vs. $8 \mathrm{~d})$ and temperature $\left(21{ }^{\circ} \mathrm{C}, 13^{\circ} \mathrm{C}\right.$ and $\left.10^{\circ} \mathrm{C}\right)$. The proportionality of hazards (PH) was checked with Martingale residuals (Lin et al. 1993, Lee \& Wang 2013). Because the $\mathrm{PH}$ assumption was violated, time-dependent covariates representing the interaction of the original covariates and time were added to the model. Time $(t)$ was defined as dichotomous: $t$ $\leq 15 \mathrm{~d}$ or $t>15 \mathrm{~d}$. These time intervals contained a sufficient number of deaths to estimate regression coefficients reliably (Anderson \& Senthilselvan 1982, Hess 1995). Custom hazard 
ratios were produced by means of contrasts. The interaction Temperature $\times$ Duration of field exposure was not replicated due to logistic constraint. Therefore, one limitation of our approach is that it did not allow us to unambiguously separate the interaction effect from among-tank differences, and inferential statistics should be interpreted with caution (Hurlbert 1984).

\subsubsection{Logistic regression}

Logistic regression models were used to investigate the effect of duration of field exposure (5d vs. $8 \mathrm{~d})$, temperature treatment $\left(10^{\circ} \mathrm{C}\right.$ vs. $\left.13^{\circ} \mathrm{C}\right)$, duration of temperature treatment and their mutual interactions on survival of oysters at the end of the challenge experiments (thermal challenge and field transfer). In these models, survival was based on the number of animals used at the onset of the challenge experiments, and mortality which may have occurred during the low temperature treatment was not taken into account.

\section{Results}

\subsection{Low temperature treatments}

Survival of oysters that had returned to the laboratory varied as function of temperature and duration of field exposure (Fig. 3). During the first 15 days, the odds of oyster mortality were ca. 2.6 times higher at $21^{\circ} \mathrm{C}$ than at low temperatures $\left(10^{\circ} \mathrm{C}\right.$ or $13^{\circ} \mathrm{C}$, Table 1). For instance, average survival of oysters previously exposed to field condition was $79.6 \%$ after $13 \mathrm{~d}$ at low temperatures in the laboratory, compared to only $23.0 \%$ at $21^{\circ} \mathrm{C}$ (Fig. 3). During this time, the odds of mortality at $13^{\circ} \mathrm{C}$ and $10^{\circ} \mathrm{C}$ were not significantly different (Table 1). However, during the next time interval (15-83d), the odds of oyster mortality were $c a .1 .3$ times higher at $13^{\circ} \mathrm{C}$ than at $10^{\circ} \mathrm{C}$ (Table 1 ). In addition, the odds of mortality increased with duration of field exposure when oysters were placed at low temperatures. This effect was particularly obvious at $13^{\circ} \mathrm{C}$ where the odds of mortality of oysters exposed for $8 \mathrm{~d}$ in the field was 2.6 times higher than that of oysters exposed for only $5 \mathrm{~d}$ (Table 1, interaction "Temperature $\times$ Duration of field exposure").

Overall, temperature strongly influenced final survival of oysters (survival after 80-83 $\mathrm{d}$ at $10^{\circ} \mathrm{C}=74.8 \%$ and at $13^{\circ} \mathrm{C}=67.5 \%$, and after $13 \mathrm{~d}$ at $21^{\circ} \mathrm{C}=23.0 \%$, Fig. 3). It is worth noting that the survival of oysters left in the field was only $14.3 \pm 4.6 \%$ by the end of the experiment, whereas survival of naïve oysters at low temperatures was $100 \%$ (data not shown).

At the onset of the temperature treatments, levels of OsHV-1 DNA in oysters previously exposed to field conditions for $5 \mathrm{~d}$ and $8 \mathrm{~d}$ in the Bay of Brest were $1.0 \times 10^{8}$ and $1.3 \times 10^{7}$ 
copies $\mathrm{mg}^{-1}$ respectively (Table 2). In contrast, OsHV-1 DNA was not detected in naïve oysters maintained in the laboratory at these times. Therefore, oysters became infected by OsHV-1 by means of brief exposure to field conditions for $5 \mathrm{~d}$ or $8 \mathrm{~d}$ in areas where mortalities were occurring, whereas OsHV-1 DNA remained undetected in naïve oysters. Given these results, oysters exposed to field conditions and further used in low temperature treatments were infected by OsHV-1. OsHV-1 $\mu$ Var-specific PCR analyses performed on these samples detected OsHV-1 $\mu$ Var genotype only.

OsHV-1 DNA in oysters previously exposed to field conditions for $5 \mathrm{~d}$ became undetectable (or unquantifiable) after only $6 \mathrm{~d}$ at $10^{\circ} \mathrm{C}$ and it was not detected after $21 \mathrm{~d}$. Similarly, OsHV$1 \mathrm{DNA}$ in oysters exposed to other low temperature treatments $\left(5 \mathrm{~d}\right.$ and $13^{\circ} \mathrm{C}, 8 \mathrm{~d}$ and $10^{\circ} \mathrm{C}, 8$ $\mathrm{d}$ and $13^{\circ} \mathrm{C}$ ) decreased with time, up until becoming not quantifiable or not detected (Table 2).

\subsection{Challenge experiments}

\subsubsection{Thermal challenges in the laboratory}

Cold-acclimated oysters exposed to a thermal elevation at $21{ }^{\circ} \mathrm{C}$ in the laboratory exhibited high levels of mortality (Table 3) whereas control oysters (those not previously exposed to field conditions but maintained at low temperature in the laboratory before thermal challenge) showed no mortality (data not shown). Survival of oysters at $21^{\circ} \mathrm{C}$ under laboratory conditions varied as a function of duration of field exposure (logistic regression model, Wald $\chi^{2}=127.2, \mathrm{p}<0.001$ ) and temperature treatment (Wald $\chi 2=129.1, \mathrm{p}<0.001$ ). In contrast to the low temperature treatment, the odds of oyster mortality were $c a$. 2.1 times higher in animals exposed to $10^{\circ} \mathrm{C}$ than $13^{\circ} \mathrm{C}$ (odds ratio $13^{\circ} \mathrm{C}$ vs. $10^{\circ} \mathrm{C}=0.472$ ). Also, odds of mortality were $\mathrm{ca} .2 .1$ times higher in oysters exposed for $5 \mathrm{~d}$ in the field compared to that of animals exposed for 8 $\mathrm{d}$ (odds ratio $8 \mathrm{~d}$ vs. $5 \mathrm{~d}=0.475$ ).

Overall, cumulative survival of oysters exposed to low temperature and then to $21^{\circ} \mathrm{C}$ was $41.4 \%( \pm 9.6$, Table 3$)$, which is somewhat higher than that of animals directly placed at $21^{\circ} \mathrm{C}$ in the laboratory $(23.0 \%)$ or those left in the field, not exposed to laboratory conditions $(14.3$ $\%)$.

Cold-acclimated oysters, previously infected with OsHV-1, and further exposed to a thermal elevation to $21^{\circ} \mathrm{C}$ in the laboratory, showed high level of OsHV-1 DNA in at least one of the two sampling dates (Table 4). In contrast, OsHV-1 DNA was not detected in control oysters maintained at $21^{\circ} \mathrm{C}$ throughout the experiment. 


\subsubsection{Field transfer}

Survival of oysters transferred back to the field varied as a function of duration of previous field exposure (logistic regression model, Wald $\chi 2=48.8, \mathrm{p}<0.001$ ), temperature treatment (Wald $\chi 2=52.1, \mathrm{p}<0.001$ ) and duration of low temperature treatment (Wald $\chi 2=125.7$, $\mathrm{p}<0.001)$. In contrast to the low temperature treatment, odds of mortality of oysters returned to the field were $c a$. 1.8 times higher in animals exposed to $10^{\circ} \mathrm{C}$ than $13^{\circ} \mathrm{C}$ (odds ratio $13^{\circ} \mathrm{C}$ vs. $10^{\circ} \mathrm{C}=0.545$ ). Also, odds of mortality were $c a$. 1.8 times higher in oysters exposed for $5 \mathrm{~d}$ in the field compared to that of animals exposed for $8 \mathrm{~d}$ (odds ratio $8 \mathrm{~d}$ vs. $5 \mathrm{~d}=0.556$ ). Finally, odds of mortality were markedly higher in oysters exposed to low temperature for less than $64 \mathrm{~d}$ compared to that of animals exposed for $64 \mathrm{~d}$ (odds ratio $64 \mathrm{~d}$ vs. others $=0.066$ ).

Overall, cumulative survival of infected oysters exposed to low temperature and then transferred back to the field was only $20.2 \% \pm 7.9$ (Table 3 ), which is similar to that of oysters not previously infected with OsHV-1 but exposed to low temperature $(17.5 \% \pm 7.7)$ and to that of oysters not previously infected with OsHV-1 and maintained at $21^{\circ} \mathrm{C}(22.2 \% \pm 9.9)$. It is noteworthy that odds of mortality were lower in control oysters transferred to the field at 64 $\mathrm{d}$ compared to that of animals transferred before (odds ratio $64 \mathrm{~d}$ vs. others $=0.066$ ), as previously reported in cold-acclimated oysters.

\section{Discussion}

In our study, the survival of oysters infected with OsHV-1, by means of short exposure to field conditions where disease related mortality occurred, was markedly improved by means of low temperature treatment, as previously reported (Petton et al. 2013). Indeed, survival of oysters at the end of the temperature treatment was $74.8 \%$ and $67.5 \%$ at $10^{\circ} \mathrm{C}$ and $13^{\circ} \mathrm{C}$ respectively compared to only $23 \%$ at $21^{\circ} \mathrm{C}$. Also, level of OsHV-1 DNA in oyster tissues decreased gradually during cold-exposure, up until becoming hardly detectable after $24 \mathrm{~d}$. It is therefore likely that low temperature treatments reduce viral replication. Indeed, replication of herpes viruses relies on the host cell machinery (Lyman \& Enquist 2009), which may correlate with temperature-dependant physiological rates in oysters (Bougrier et al. 1995).

Interestingly, survival of oysters in the laboratory at low temperature decreased with duration of field exposure in a way similar to a dose-response relationship, as previously reported at $21^{\circ} \mathrm{C}$ (Petton et al. 2015). This result suggests that the survival improvement due to low temperature treatments decrease with infectious pressure.

Our results show that OsHV-1 is persistent in oysters at low temperature $\left(<13^{\circ} \mathrm{C}\right)$ and it is reactivated during thermal elevation to $21^{\circ} \mathrm{C}$. A similar pattern was reported in common carp 
Cyprinus carpio exposed to Koi herpesvirus (KHV) (St-Hilaire et al. 2005). For instance, fish infected with $\mathrm{KHV}$ and further maintained at $12^{\circ} \mathrm{C}$, a temperature below the threshold value of $16^{\circ} \mathrm{C}$ at which the virus is active, exhibited no mortality for 30 weeks, but mortality was observed when temperature was increased to $23^{\circ} \mathrm{C}$. Therefore, the reactivation of the virus can occur several weeks to months after the initial exposure and appears to be temperature dependent.

Overall survival of oyster seed infected with OsHV-1 was not improved by low temperature treatment. This result contrasts with a previous study where cold-acclimated oysters infected with OsHV-1 did not exhibit any mortality at $21^{\circ} \mathrm{C}$ and OsHV-1 DNA was not detected (Petton et al. 2013). In both studies, diseased oysters were not injected with OsHV-1, but were instead exposed to field conditions in which disease-related mortality was occurring, so that the concentration of infective particles was not controlled and it may have varied between studies. In support of this hypothesis, survival of oysters previously exposed to field conditions for 5 days was only $23 \%$ in our study compared to $60-100 \%$ in 2011 (Petton et al. 2015). Furthermore, the duration of field exposure required to observe the first mortality was $\sim 14 \mathrm{~d}$ when Petton et al. (2013) did their experiments, compared to only $9 \mathrm{~d}$ in the present study (unpublished data). Differences between studies likely reflect the differences in the infective dose faced by the oysters during field exposure.

\section{Conclusion}

The present study showed that overall survival of oyster seed infected with OsHV-1 was not improved by low temperature treatments, which temper the previous results of Petton et al. (2013). Consequently, low temperature treatments do not reliably remedy infection with OsHV-1. From a practical standpoint, our study suggests that moving infected oysters to a cooler area before the onset of mortality to limit mortality is not a good practice. Indeed, these infected animals will likely exhibit high mortality once temperature permits virus replication, as reported in the present study. Survival of oysters may not be improved, and the risk of disease transmission to neighbouring stocks can be high. Finally, our study supports the idea that thermal elevation of oysters at $21^{\circ} \mathrm{C}$, by revealing asymptomatic carriers of OsHV-1, is complementary to PCR assays for characterising the health status of oysters (Petton et al. 2015).

\section{Acknowledgments}

The authors thank all the staffs involved in oyster production at Ifremer Argenton and the shellfish networks (Resco and Velyger) for providing temperature measurements. This work 
was supported by the French Ministry of Ecology, Sustainable Development, Transport and Housing (Convention DPMA 2013 - Ifremer 2012/1/1210320/NYF) and is part of the GIGASSAT project funded by ANR-AGROBIOSPHERE NANR-12-AGRO-0001-01.

David Tamayo was supported by the grant "Programa Posdoctoral de Perfeccionamiento de doctores del Gobierno Vasco". Thanks are given to Flavia Nunes, for the help provided in improving the manuscript.

\section{References}

Anderson JA, Senthilselvan A (1982) A Two-Step Regression Model for Hazard Functions. J R Stat Soc Ser C Appl Stat 31:44-51

Bougrier S, Geairon P, Deslouspaoli JM, Bacher C, Jonquieres G (1995) Allometric relationships and effects of temperature on clearance and oxygen-consumption rates of Crassostrea gigas (Thunberg). Aquaculture 134:143-154

Cox DR (1972) Regression Models and Life Tables. J R Stat Soc Series B Stat Methodol 20:187-220

EFSA (2010) Scientific Opinion of the Panel on Animal Health and Welfare on a request from the European Commission on the increased mortality events in Pacific oysters Crassostrea gigas. EFSA 8:1894-1953

Hess KR (1995) Graphical methods for assessing violations of the proportional hazards assumption in cox regression. Stat Med 14:1707-1723

Hurlbert SH (1984) Pseudoreplication and the design of ecological field experiments. Ecol Monogr 54:187-211

Kaplan EL, Meier P (1958) Nonparametric Estimation from Incomplete Observations. J Am Stat Assoc 53:457481

Lee ET, Wang JW (2013) Statistical Methods for Survival Data Analysis. Wiley

Lin DY, Wei LJ, Ying Z (1993) Checking the Cox Model with Cumulative Sums of Martingale-Based Residuals. Biometrika 80:557-572

Lyman MG, Enquist LW (2009) Herpesvirus Interactions with the Host Cytoskeleton. J Virol 83:2058-2066

Lynch SA, Carlsson J, Reilly AO, Cotter E, Culloty SC (2012) A previously undescribed ostreid herpes virus 1 (OsHV-1) genotype detected in the Pacific oyster, Crassostrea gigas, in Ireland. Parasitology 139:15261532

Martenot C, Oden E, Travaille E, Malas J-P, Houssin M (2011) Detection of different variants of Ostreid Herpesvirus 1 in the Pacific oyster, Crassostrea gigas between 2008 and 2010. Virus Res 160:25-31

Peeler EJ, Reese RA, Cheslett DL, Geoghegan F, Power A, Thrush MA (2012) Investigation of mortality in Pacific oysters associated with Ostreid herpesvirus-1 $\mu$ Var in the Republic of Ireland in 2009. Prev Vet Med 105:136-143

Pepin JF, Riou A, Renault T (2008) Rapid and sensitive detection of ostreid herpesvirus 1 in oyster samples by real-time PCR. J Virol Methods 149:269-276

Pernet F, Barret J, Gall PL, Corporeau C, Dégremont L, Lagarde F, Pépin J-F, Keck N (2012) Mass mortalities of Pacific oysters Crassostrea gigas reflect infectious diseases and vary with farming practises in the Thau lagoon. Aquaculture Env Interact 2:215-237

Petton B, Boudry P, Alunno-Bruscia M, Pernet F (2015) Factors influencing disease-induced mortality of Pacific oysters Crassostrea gigas. Aquaculture Env Interact 6:205-222

Petton B, Pernet F, Robert R, Boudry P (2013) Temperature influence on pathogen transmission and subsequent mortalities in juvenile Pacific oysters Crassostrea gigas. Aquaculture Env Interact 3:257-273

Pfeiffer DU (2010) Veterinary Epidemiology: An Introduction. John Wiley \& Sons

Renault T, Bouquet AL, Maurice J-T, Lupo C, Blachier P (2014) Ostreid Herpesvirus 1 Infection among Pacific Oyster (Crassostrea gigas) Spat: Relevance of Water Temperature to Virus Replication and Circulation Prior to the Onset of Mortality. Appl Environ Microbiol 80:5419-5426

Renault T, Moreau P, Faury N, Pepin J-F, Segarra A, Webb S (2012) Analysis of clinical ostreid herpesvirus 1 (Malacoherpesviridae) specimens by sequencing amplified fragments from three virus genome areas. $\mathrm{J}$ Virol 86(10): 5942-5947.

Roque A, Carrasco N, Andree KB, Lacuesta B, Elandaloussi L, Gairin I, Rodgers CJ, Furones MD (2012) First report of OsHV-1 microvar in Pacific oyster (Crassostrea gigas) cultured in Spain. Aquaculture 324 325:303-306 
Segarra A, Pepin JF, Arzul I, Morga B, Faury N, Renault T (2010) Detection and description of a particular Ostreid herpesvirus 1 genotype associated with massive mortality outbreaks of Pacific oysters, Crassostrea gigas, in France in 2008. Virus Res 153:92-99

St-Hilaire S, Beevers N, Way K, Le Deuff RM, Martin P, Joiner C (2005) Reactivation of koi herpesvirus infections in common carp Cyprinus carpio. Dis Aquat Org 67:15-23

Webb SC, Fidler A, Renault T (2007) Primers for PCR-based detection of ostreid herpes virus-1 (OsHV-1): Application in a survey of New Zealand molluscs. Aquaculture 272:126-139 
Table 1. Odds of oyster mortality as a function of temperature treatments $\left(21^{\circ} \mathrm{C}, 13^{\circ} \mathrm{C}\right.$ and $10^{\circ} \mathrm{C}$ ) and duration of field exposure ( $8 \mathrm{~d}$ vs. $5 \mathrm{~d}$ ) for each time interval (0-15d and 15-83d). Custom hazard ratios were produced by means of exponentiated contrasts. The table also contains the standard error (SE) of the hazard ratio estimate and the confidence interval (CI) on the hazard ratio, the Wald $\chi 2$ statistic and the resulting $p$-value.

\begin{tabular}{llllll}
\hline Variable & Odds ratio & SE & $95 \%$ CI & Wald $\chi^{2}$ & p \\
\hline $0-15 d$
\end{tabular}

\section{0-15d}

Temperature:

$21^{\circ} \mathrm{C}$ vs. $\left(10^{\circ} \mathrm{C}\right.$ and $\left.13^{\circ} \mathrm{C}\right)$

2.611

0.219

2.214-3.077

130.6

$<0.001$

$13^{\circ} \mathrm{C}$ vs. $10^{\circ} \mathrm{C}$

1.000

0.036

0.932-1.073

0.0

0.999

Duration of field exposure:

$8 \mathrm{~d}$ vs. $5 \mathrm{~d}$

$$
0.876
$$

0.052

$0.779-0.984$

4.9

0.026

Temperature $\times$ Duration:

8d vs 5d@21 ${ }^{\circ} \mathrm{C}$

0.699

0.114

0.507-0.963

4.8

0.029

8d vs 5d@13ㄷ

0.964

$0.049 \quad 0.873-1.064$

0.5

0.466

8d vs 5d@10 $\mathrm{C}$

0.971

$0.049 \quad 0.879-1.072$

$0.3 \quad 0.560$

\section{5-83d}

Temperature:

$13^{\circ} \mathrm{C}$ vs. $10^{\circ} \mathrm{C}$

1.339

$0.031 \quad 1.279-1.401$

157.6

$<0.001$

Duration of field exposure:

$8 \mathrm{~d}$ vs. $5 \mathrm{~d}$

0.047

1.900-2.086

842.4

$<0.001$

Temperature $\times$ Duration:

8d vs. 5d@13ㄷ

8d vs. 5d @ $10^{\circ} \mathrm{C}$

1.532

$0.050 \quad 1.437-1.634$

170.3 $<0.001$ 
Table 2. Detection of OsHV-1 (number of DNA copies mg-1) in oysters as a function of duration of field exposure $(5 \mathrm{~d}$ or $8 \mathrm{~d})$, temperature treatment $\left(10^{\circ} \mathrm{C}\right.$ and $\left.13^{\circ} \mathrm{C}\right)$ and time since the onset of the temperature treatment.

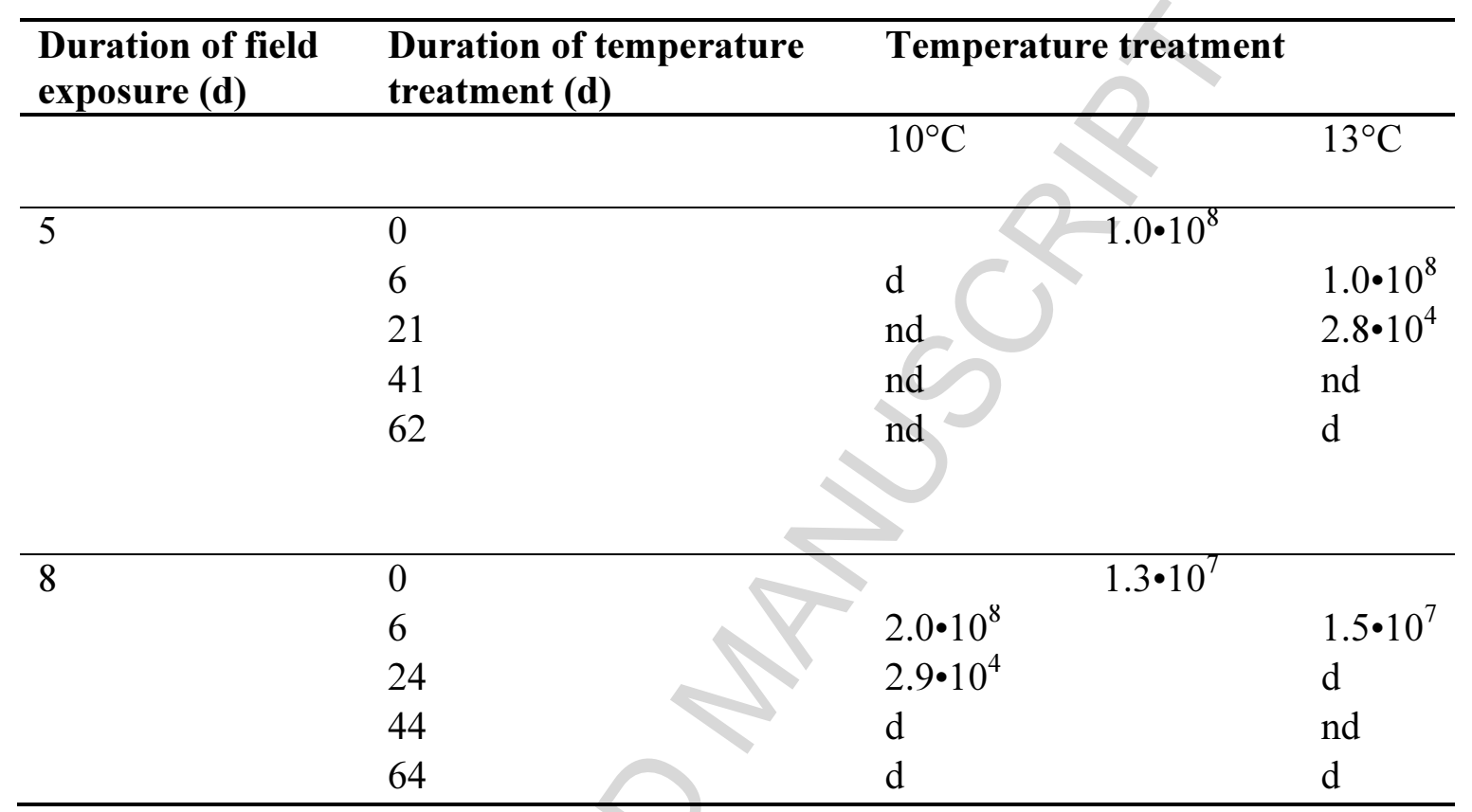

Abbreviations: d: detected but not quantified, nd: not detected. 
Table 3. Survival of oysters held at $21^{\circ} \mathrm{C}$ for $20 \mathrm{~d}$ in the laboratory as a function of previous field exposure $(5 \mathrm{~d}$ or $8 \mathrm{~d})$, temperature treatment in the laboratory $\left(10^{\circ} \mathrm{C}\right.$ or $\left.13^{\circ} \mathrm{C}\right)$ and duration of the temperature treatment. Data are means \pm SD ( $n=2$ replicate tanks). Numbers in brackets indicate survival of oysters taking into account for mortality occurring during low temperature treatments ${ }^{1}$.

\begin{tabular}{|c|c|c|c|c|}
\hline \multirow[t]{2}{*}{$\begin{array}{l}\text { Duration of } \\
\text { field } \\
\text { exposure (d) }\end{array}$} & $\begin{array}{l}\text { Duration of } \\
\text { temperature } \\
\text { treatment (d) }\end{array}$ & \multicolumn{3}{|c|}{ Temperature treatment } \\
\hline & & $10^{\circ} \mathrm{C}$ & $13^{\circ} \mathrm{C}$ & \\
\hline \multirow[t]{4}{*}{5} & 6 & $39.4 \pm 4.3$ & $67.3 \pm 6.3$ & $(67.2)$ \\
\hline & 21 & $41.2 \pm 21.0$ & $40.2 \pm 11.1$ & $(37.9)$ \\
\hline & 41 & $34.9 \pm 18.3$ & $54.9 \pm 0.1$ & $(51.1)$ \\
\hline & 62 & $49.5 \pm 3.7$ & $59.8 \pm 5.2$ & $(55.2)$ \\
\hline \multirow[t]{4}{*}{8} & 6 & $40.8 \pm 0.2$ & $60.8 \pm 2.3$ & (44.9) \\
\hline & 24 & $65.2 \pm 4.7$ & $77.4 \pm 1.5$ & $(35.0)$ \\
\hline & 44 & $68.3 \pm 0.7$ & $80.4 \pm 3.0$ & $(34.7)$ \\
\hline & 64 & $56.6 \pm 2.4$ & $82.6 \pm 0.0$ & $(35.3)$ \\
\hline
\end{tabular}

${ }^{1}$ the overall survival which take into account the two phases of the experiment (low temperature treatment and thermal challenge) was calculated as follows:

$\mathrm{S}_{\mathrm{all}}=\mathrm{S}_{\text {cold }}+\left[\mathrm{S}_{21^{\circ} \mathrm{C}}-\left(\mathrm{S}_{\text {cold }} \times \mathrm{S}_{21^{\circ} \mathrm{C}}\right)\right]$

where $S_{\text {all }}$ is the overall survival, $S_{\text {cold }}$ and $S_{21^{\circ} \mathrm{C}}$ correspond to the observed survival during low temperature treatment and thermal challenge respectively. 
Table 4. Detection of OsHV-1 (number of DNA copies $\mathrm{mg}^{-1}$ ) in oysters as a function of duration of field exposure $(5 \mathrm{~d}$ or $8 \mathrm{~d})$, temperature $\left(10^{\circ} \mathrm{C}\right.$ and $\left.13^{\circ} \mathrm{C}\right)$ and duration of the temperature treatment, and time since the onset of the temperature elevation at $21^{\circ} \mathrm{C}$.

\begin{tabular}{|c|c|c|c|c|}
\hline \multirow[t]{2}{*}{$\begin{array}{l}\text { Duration } \\
\text { of field } \\
\text { exposure } \\
\text { (d) } \\
\end{array}$} & \multirow[t]{2}{*}{$\begin{array}{l}\text { Duration of } \\
\text { temperature } \\
\text { treatment }(d)\end{array}$} & \multirow[t]{2}{*}{$\begin{array}{l}\text { Time since } \\
\text { temperature } \\
\text { elevation at } 21^{\circ} \mathrm{C} \\
\text { (d) }\end{array}$} & \multicolumn{2}{|c|}{ Temperature treatment } \\
\hline & & & $10^{\circ} \mathrm{C}$ & $13^{\circ} \mathrm{C}$ \\
\hline \multirow[t]{8}{*}{5} & 6 & 4 & $1.0 \cdot 10^{8}$ & $8.0 \cdot 10^{7}$ \\
\hline & & 15 & $7.9 \cdot 10^{7}$ & nd \\
\hline & 21 & 3 & $1.3 \cdot 10^{4}$ & $\mathrm{~d}$ \\
\hline & & 20 & $\mathrm{~d}$ & $1.2 \cdot 10^{5}$ \\
\hline & 41 & 4 & nd & $2.0 \cdot 10^{8}$ \\
\hline & & 21 & nd & $1.7 \cdot 10^{4}$ \\
\hline & 62 & 4 & $1.0 \cdot 10^{8}$ & $1.0 \cdot 10^{8}$ \\
\hline & & 18 & $2.5 \cdot 10^{4}$ & $\mathrm{~d}$ \\
\hline \multirow[t]{8}{*}{8} & 6 & 4 & $1.2 \cdot 10^{5}$ & $\mathrm{~d}$ \\
\hline & & & $\mathrm{d}$ & $3.2 \cdot 10^{6}$ \\
\hline & 24 & & $\mathrm{~d}$ & $2.2 \cdot 10^{5}$ \\
\hline & & & nd & $2.5 \cdot 10^{6}$ \\
\hline & 44 & 4 & $6.3 \cdot 10^{6}$ & nd \\
\hline & & 21 & $\mathrm{~d}$ & $\mathrm{~d}$ \\
\hline & 64 & 4 & $2.0 \cdot 10^{8}$ & $2.4 \cdot 10^{7}$ \\
\hline & & 15 & $1.1 \cdot 10^{5}$ & $6.8 \cdot 10^{4}$ \\
\hline
\end{tabular}

Abbreviations: d: detected but not quantified, nd: not detected. 
Table 5. Survival of oysters transferred in the field as a function of previous field exposure (5 $\mathrm{d}$ or $8 \mathrm{~d})$, temperature treatment in the laboratory $\left(10^{\circ} \mathrm{C}\right.$ or $\left.13^{\circ} \mathrm{C}\right)$ and duration of the temperature treatment. Data are means $\pm S D(n=2$ and $n=4$ replicate tanks for and infected and non-infected oysters respectively). Numbers in brackets indicate survival of oysters taking into account for mortality occurring during low temperature treatments ${ }^{1}$.

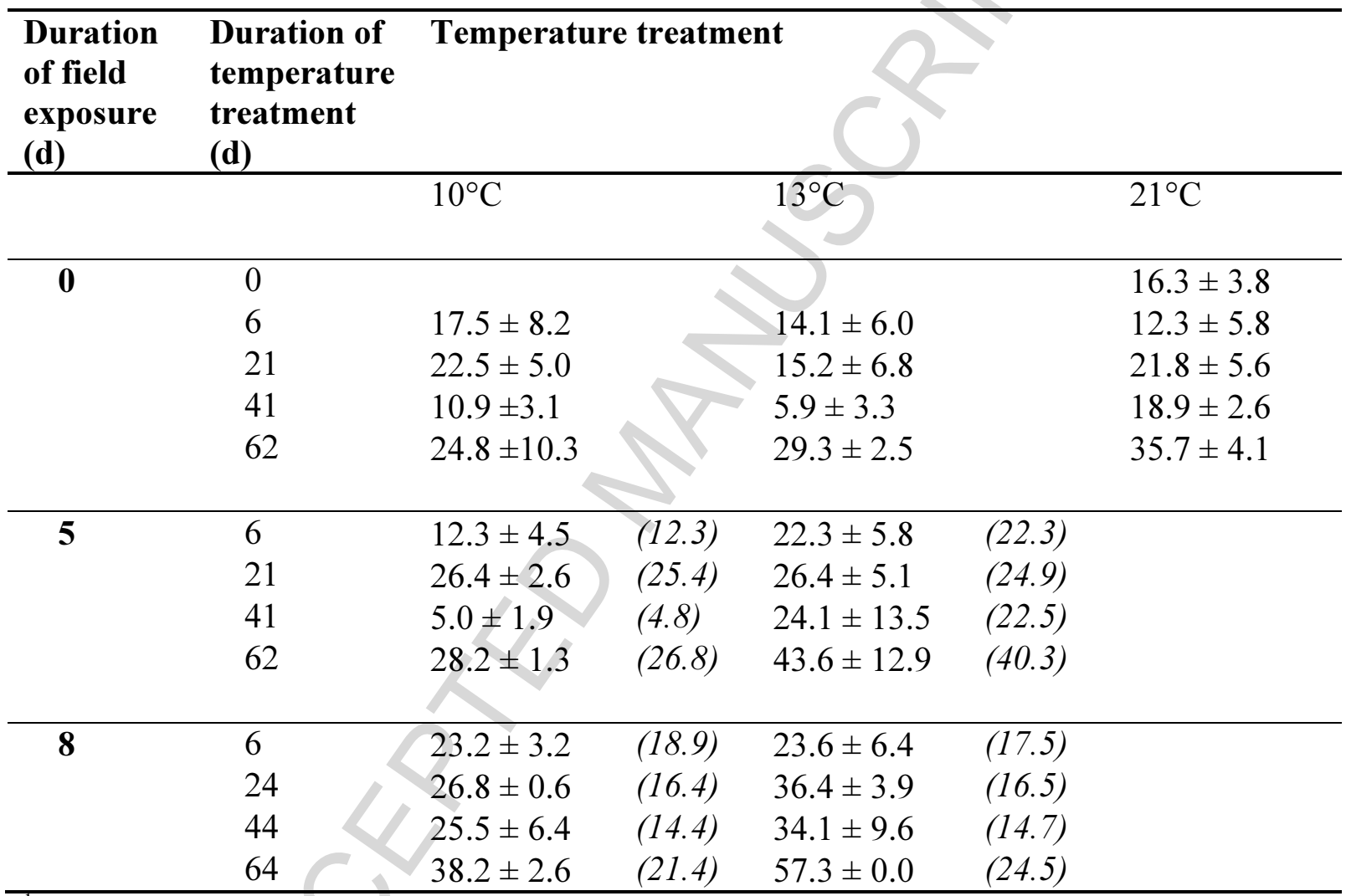

\footnotetext{
${ }^{1}$ the overall survival which take into account the two phases of the experiment (low temperature treatment and field transfer) was calculated as follows:

$\mathrm{S}_{\mathrm{all}}=\mathrm{S}_{\text {cold }}+\left[\mathrm{S}_{\text {Field }}-\left(\mathrm{S}_{\text {cold }} \times \mathrm{S}_{\text {Field }}\right)\right]$,

where $S_{\text {all }}$ is the overall survival, $S_{\text {cold }}$ and $S_{21^{\circ} \mathrm{C}}$ correspond to the observed survival during low temperature treatment and thermal challenge respectively.
} 


\section{Figure legends}

Figure 1. Experimental design.

Figure 2. Evolution of seawater temperature during the period of study in 2013 within the bivalve farming area located in the Bay of Brest at Pointe du Chateau (northern Brittany, France, $\left(48^{\circ} 20^{\prime} 06.19^{\prime \prime} \mathrm{N}, 4^{\circ} 19^{\prime} 06.37^{\prime \prime} \mathrm{W}\right)$. Circles indicate the dates on which oysters were challenged in the field.

Figure 3. Survival of oysters Crassostrea gigas under laboratory conditions at $21^{\circ} \mathrm{C}$ (red), $13^{\circ} \mathrm{C}$ (orange) and $10^{\circ} \mathrm{C}$ (blue) following exposure to field conditions for $5 \mathrm{~d}$ (dotted line) or 8 $\mathrm{d}$ (plain line), in an area where disease-induced mortalities were occurring. Survival time was measured as days from the end of the field exposure period / the onset of the temperature treatment. 
Low temperature treatments

\begin{tabular}{|c|c|c|c|c|c|c|c|}
\hline d-5 & do & d3 & d6 & d 21 & $\mathrm{~d} 41$ & d62 & d83 \\
\hline $5 / 7$ & $9 / 7$ & $12 / 7$ & $15 / 7$ & $30 / 7$ & $19 / 8$ & $9 / 9$ & $30 / 9$ \\
\hline
\end{tabular}

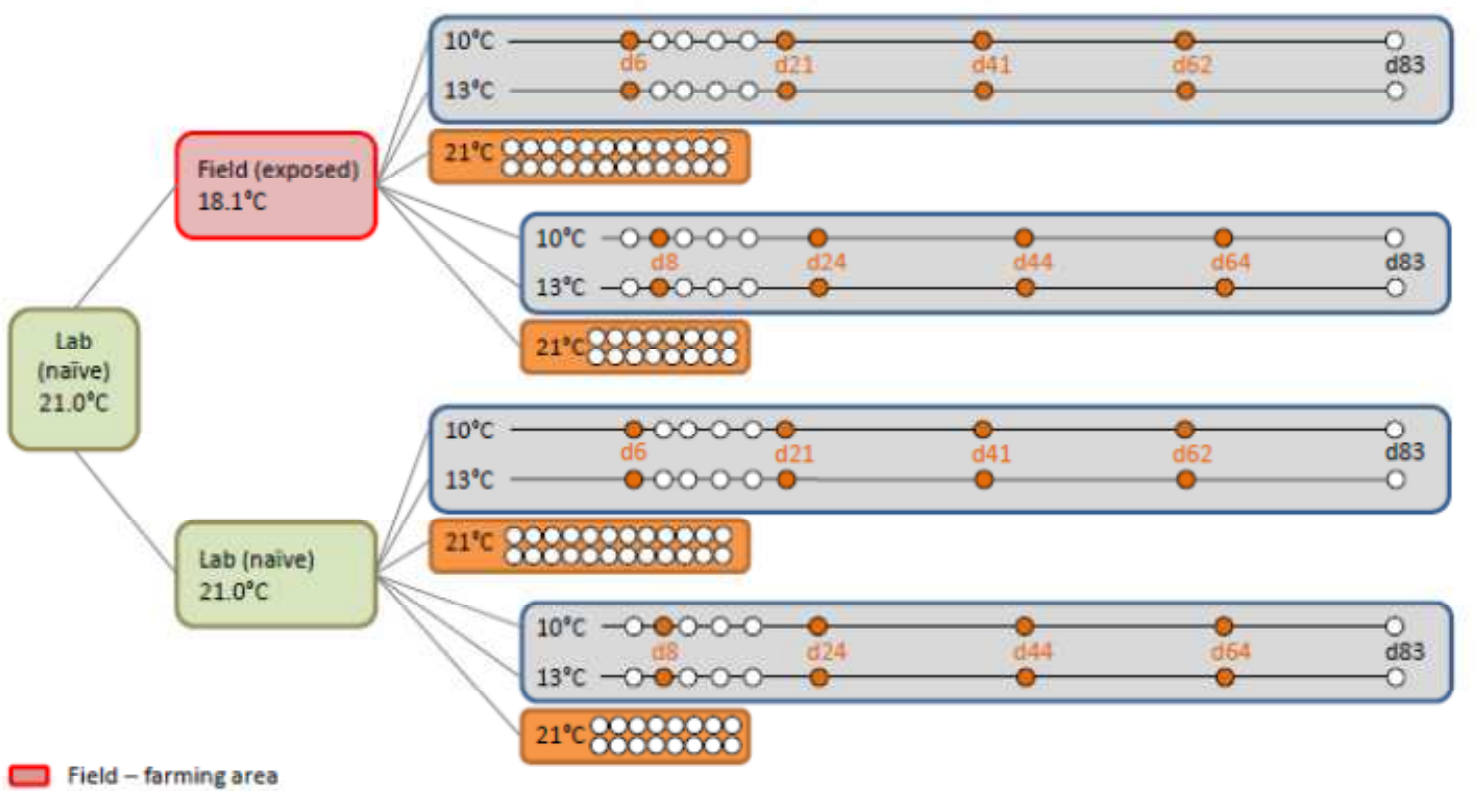

$\square$ Lab-low temperature room $(500-\mathrm{L}$ tanks)

$\square$ Lab-High temperature room used for naive oysters at $21^{\circ} \mathrm{C}(500-\mathrm{L}$ tanks)

$\square$ Lab-high temperature room used for thermal challenge at $21^{\circ} \mathrm{C}(23-\mathrm{L}$ tanks)

O Survival

Survival, OsHV-1, and Challenge experiments
Challenge experiments

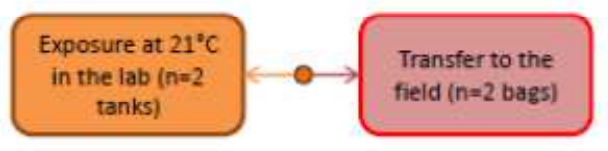

Figure 1 


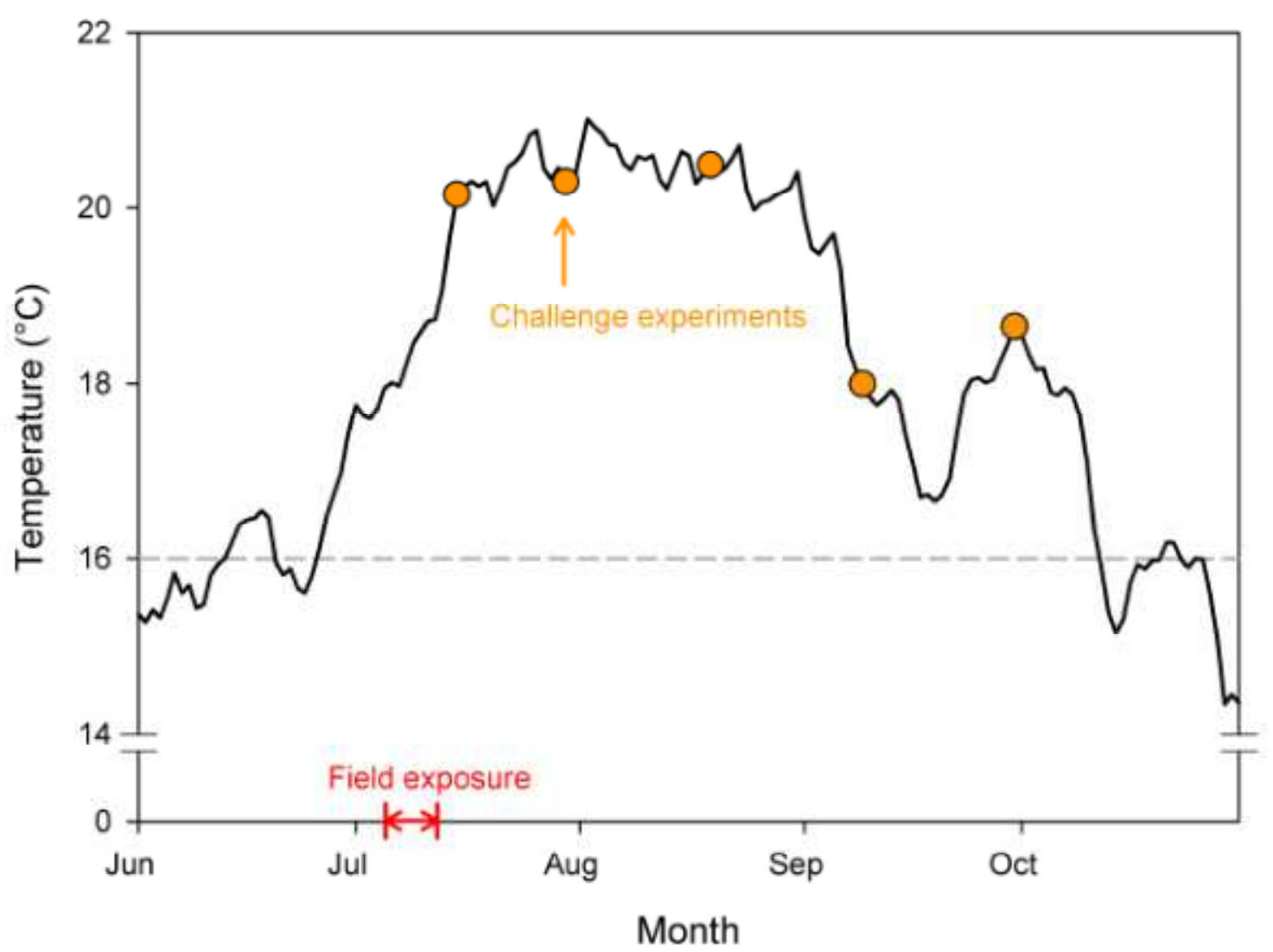

Fig. 2 


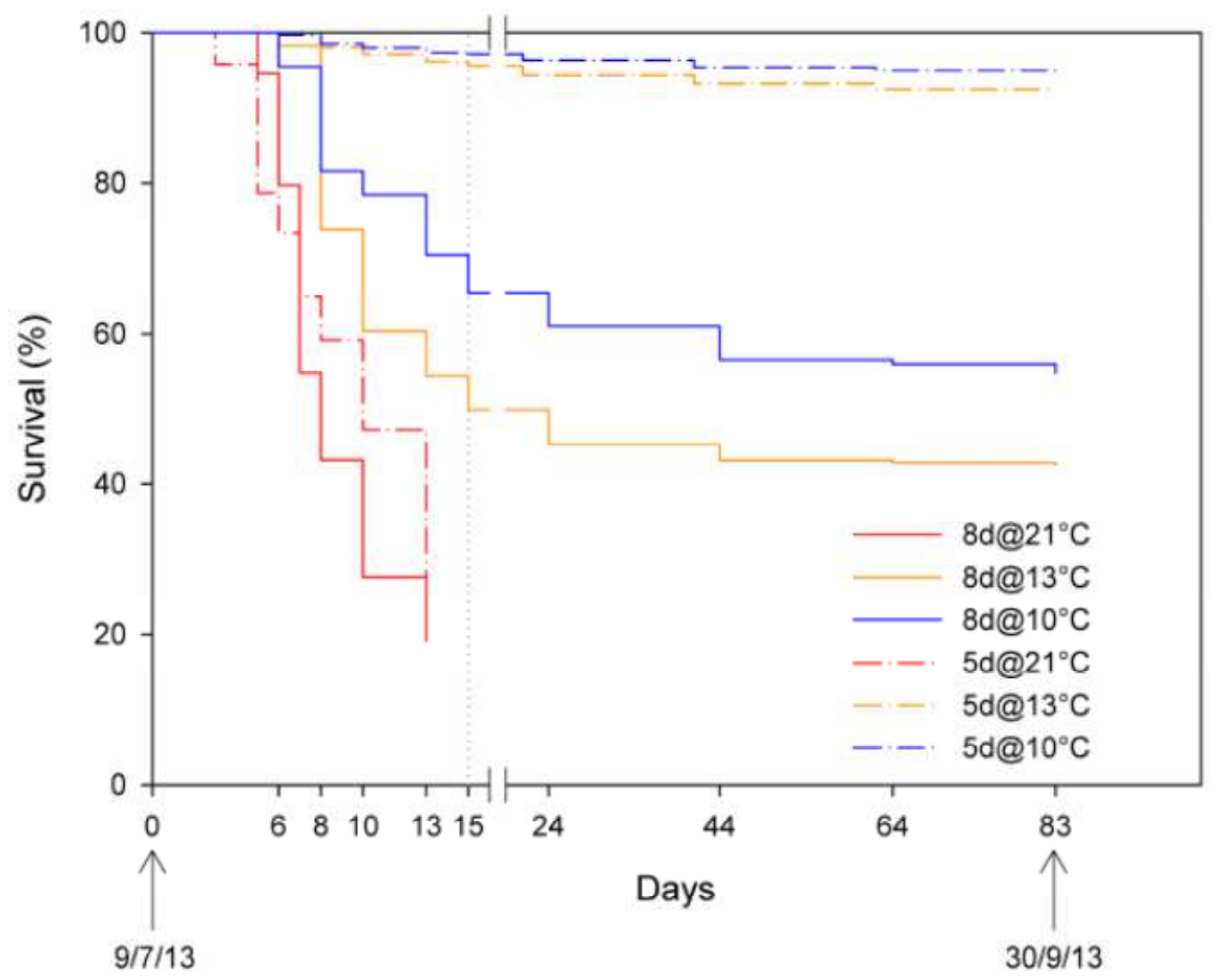

Fig. 3 